\title{
A SOCIALIZAÇÃO DA SOCIEDADE ${ }^{1}$
}

\author{
Rosa Luxemburg 2
}

A revolução do proletariado, que acaba de começar, não pode ter nenhum outro fim nem nenhum outro resultado a não ser a realização do socialismo. Antes de tudo, a classe operária precisa tentar obter todo o poder político estatal. Mas para nós, socialistas, o poder político é apenas meio. O fim para o qual precisamos utilizar o poder é a transformação radical da situação econômica como um todo.

Hoje, todas as riquezas _ as maiores e melhores terras, as minas e empresas, assim como as fábricas - pertencem a alguns poucos latifundiários e capitalistas privados. A grande massa dos trabalhadores, por um árduo trabalho, recebe apenas desses latifundiários e capitalistas um parco salário para viver. $\mathrm{O}$ enriquecimento de um pequeno número de ociosos é o objetivo da economia atual.

Esta situação deve ser eliminada. Todas as riquezas sociais, o solo com todos os tesouros que abriga no interior e na superfície, todas as fábricas e empresas, enquanto propriedades comuns do povo, precisam ser tiradas das mãos dos exploradores. O primeiro dever de um verdadeiro governo operário consiste em proclamar, através de uma série de decisões soberanas, os meios de produção mais importantes como propriedade nacional e em pô-los sob o controle da sociedade.

Só então começa propriamente a mais difícil tarefa: a construção da economia em bases totalmente novas.

Hoje, em cada empresa, a produção é dirigida pelo próprio capitalista isolado. O que e como deve ser produzido, quando e como as mercadorias fabricadas devem ser vendidas é o empresário quem determina. Os trabalhadores jamais cuidam disso, eles são apenas máquinas vivas que têm de executar seu trabalho.

$\mathrm{Na}$ economia socialista tudo isso precisa ser diferente! O empresário privado desaparece. A produção não tem mais como objetivo enriquecer o indivíduo, mas fornecer à coletividade, meios de satisfazer todas as necessidades. Consequentemente, as fábricas, empresas, explorações agrícolas precisam adaptar-se segundo pontos de vista totalmente novos:

Primeiro: se a produção deve ter por objetivo assegurar a todos uma vida digna, fornecer a todos alimentação abundante, vestuário e outros meios culturais de existência, então a produtividade do trabalho precisa ser muito maior que hoje. Os campos precisam fornecer colheitas maiores, nas fábricas precisa ser utilizada a mais alta técnica; quando às minas de carvão e minério, apenas as mais rentáveis precisam ser exploradas etc. Segue-se daí que a socialização se estenderá, antes de mais nada, às grandes empresas industriais e agrícolas. Não precisamos nem queremos tirar a pequena propriedade ao pequeno agricultor e ao pequeno trabalhador que, com seu próprio trabalho, vive penosamente do seu pedacinho de terra ou da 
sua oficina. Com o tempo, todos eles virão até nós voluntariamente e compreenderão as vantagens do socialismo sobre a propriedade privada.

Segundo: para que na sociedade todos possam usufruir do bem-estar, todos precisam trabalhar. Apenas quem executa trabalho útil para a coletividade, quer trabalho manual, quer intelectual, pode exigir da sociedade meios para a satisfação de suas necessidades. Uma vida ociosa, como hoje levam na maioria das vezes os ricos exploradores, acaba. A obrigação de trabalhar para todos os que são capazes, exceto naturalmente as crianças pequenas, os velhos e os doentes é, na economia socialista, uma coisa evidente. Quando aos incapazes de trabalhar, a coletividade precisa simplesmente tomar conta dele - não como hoje, com esmolas miseráveis, mas por meio de alimentação abundante, educação pública para as crianças, boas assistências médicas pública para os doentes etc.

Terceiro: a partir do mesmo ponto de vista, isto é, do bem-estar da coletividade, é preciso que os meios de produção, assim como as forças de trabalho sejam inteligentemente administradas e economizadas. O desperdício, que ocorre hoje a cada passo, precisa acabar.

Assim, naturalmente, é preciso suprimir a indústria de guerra e de munição no seu conjunto, pois a sociedade socialista não precisa de armas assassinas. Em vez disso, é preciso que os valiosos materiais e a força de trabalho aí empregados sejam utilizados para produzir coisas úteis. As indústrias de luxo, que hoje produzem todo tipo de futilidades para os ociosos, assim como a criadagem pessoal, precisam igualmente desaparecer. Toda a força de trabalho posta nisso encontrará ocupação mais útil e mais digna.

Se desta maneira criarmos um povo de trabalhadores, em que todos trabalhem para todos, para o bem-estar e o benefício coletivos, então, quarto: o próprio trabalho precisa adquirir uma configuração inteiramente diferente. Hoje em dia, o trabalho, tanto na indústria, quanto na agricultura ou no escritório é, na maioria das vezes, uma tortura e um fardo para o proletário. As pessoas vão para o trabalho porque é preciso, caso contrário não conseguirão meios de subsistência. $\mathrm{Na}$ sociedade socialista, onde todos trabalham em conjunto para o seu bem próprio bem-estar, é preciso ter a maior consideração pela saúde e pelo prazer de trabalhar. Tempo de trabalho reduzido, que não ultrapasse a capacidade normal, locais de trabalho saudáveis, todos os meios para o descanso e o trabalho precisam ser introduzidos, para que cada um faça a sua parte com maior prazer.

Porem para todas as grandes reformas é necessário o material humano correspondente. Hoje atrás do trabalhador, esta o capitalista com seu chicote _ em pessoa, ou através de seu contra-mestre ou capataz. A fome arrasta o proletário para trabalhar na fábrica, na grande propriedade ou no escritório. O empresário cuida então para que o tempo não seja desperdiçado, para que o material não seja estragado, para que seja fornecido trabalho bom e competente.

$\mathrm{Na}$ economia socialista é suprimido o empresário com seu chicote. Aqui os trabalhadores são homens livres e iguais, que trabalham para seu próprio bem-estar e benefício. Isso significa trabalhar zelosamente por conta própria, por si mesmo, não desperdiçar a riqueza social, fornecer o trabalho mais honesto e pontual. Cada empresa socialista precisa, naturalmente, de um dirigente técnico que entenda exatamente do assunto, que estabeleça o que é mais necessário para que tudo funcione, para que seja atingida 
a divisão do trabalho mais correta e o mais alto rendimento. Ora, isso significa seguir essas ordens de boa vontade, na íntegra, manter a disciplina e a ordem, sem provocar atritos nem confusões.

Numa palavra: o trabalhador da economia socialista precisa mostrar que também pode trabalhar zelosa e ordeiramente sem o chicote da fome, sem o capitalista e seus contra-mestres atrás das costas, que pode manter a disciplina e fazer o melhor. Para isso é preciso auto-disciplina interior, maturidade moral, senso de dignidade, todo um renascimento interior do proletário.

Com homens preguiçosos, levianos, egoístas, irrefletidos e indiferentes não se pode realizar o socialismo. A sociedade socialista precisa de homens que estejam, cada um em seu lugar, cheios de paixão e entusiasmo pelo bem estar coletivo, totalmente dispostos ao sacrifício e cheios de compaixão pelo próximo, cheios de coragem e tenacidade para ousarem o mais difícil.

Porém, não precisamos esperar quase um século ou uma década até que tal espécie de homens se desenvolva. Precisamente agora, na luta, na revolução, as massas proletárias aprendem o idealismo necessário e adquirem rapidamente maturidade intelectual. Também precisamos de coragem e perseverança, clareza interna e disposição ao sacrifício para continuar a revolução até a vitória. Recrutando bons combatentes para a atual revolução, criamos futuros trabalhadores socialistas, necessários como fundamento de uma nova ordem.

A juventude trabalhadora, sobretudo, é chamada para esta grande tarefa. Como geração futura, ela formará com toda certeza o verdadeiro fundamento da economia socialista. Ela tem que mostrar já, como portadora do futuro da humanidade, que está à altura dessa grande tarefa. Há todo um velho mundo ainda por destruir e todo um novo mundo a construir. Mas nós conseguiremos, jovens amigos, não é verdade? Nós conseguiremos! Como diz o poema:

Não nos falta nada, minha mulher, meu filho, a não ser tudo que cresce através de nós, para sermos livres como os pássaros: nada, a não ser tempo!

\section{Notas:}

${ }^{1}$ Escrito em: Dezembro de 1918. 1 ${ }^{\text {a }}$ Edição: Die junge Garde (Berlin); No 2,4. December 1918. Fonte: 'Gesammelte Werke', Vol. 4, p 431-34, RDA, Berlin, 1970-75. Tradução de: Isabel Loreiro. HTML por José Braz para The Marxists Internet Archive. Direito de Reprodução: Luxemburg Internet Archive (marxists.org), 1999. A cópia ou distribuição deste documento é livre e indefinidamente garantida nos termos da GNU Free Documentation License. Extraído de Marxist Internet Archive. Disponível em: https://www.marxists.org/portugues/luxemburgo/1918/12/socializacao.htm

${ }^{2}$ Entrou para o movimento revolucionário ainda estudante. Em 1893, colaborou na fundação do Partido Social Democrata Polaco. Entrou para o Partido Social Democrata Alemão em 1898. Em 1907, em Londres, na conferência do Partido Social Democrata Russo, apoiou os bolcheviques contra os mencheviques em todos os problemas mais importantes da Revolução russa. No mesmo ano, no Congresso de Stuttgart da II Internacional, juntamente com Lenin, apresentou a proposta revolucionária contra a guerra e que foi adotada, na essência, pelo Congresso. Após a Revolução de Novembro de 1918 na Alemanha, juntou-se a Karl Liebknecht e fundaram o Partido Comunista Alemão. ${ }^{2}$ 